\title{
Hacia una cultura de la hospitalidad. El logos simbólico como acceso estético a la mística del nosotros
}

\author{
Cecilia Avenatót de Palumbo* \\ Universidad Católica Argentina (Argentina) \\ ceciliapalumbo52@gmail.com
}

\begin{abstract}
Resumen
El objetivo de este artículo es plantear la relación entre la antropología trinitaria y el lenguaje simbólico, a fin de responder al desafío de crear una cultura de la hospitalidad. Para lograr este propósito se realiza un ejercicio interdisciplinario de puesta en diálogo entre la poesía y ensayos de Octavio Paz y las tesis de ontología trinitaria de Klaus Hemmerle, a partir de lo cual se deducen las características de una mística del nosotros.
\end{abstract}

Palabras clave: Hospitalidad, mística del nosotros, antropología trinitaria, Octavio Paz, Klaus Hemmerle.

\section{Towards a culture of hospitality. The symbolic logos as an aesthetic access to the mystic of us}

\begin{abstract}
The aim of this article is to point out the relationship between the trinitary anthropology and the symbolic language, so as to give an answer to the challenge of creating a culture of hospitality. In order to achieve this, an interdisciplinary exercise of dialogue between Octavio Paz's poems and essays and Klaus Hemmerle's thesis of the trinitary onthology is carried out, from which we infer the characteristics of the mystic of us.
\end{abstract}

Key words: Hospitality, mystic of us, trinitary anthropology, Octavio Paz, Klaus Hemmerle.

\footnotetext{
* Doctora en Letras por la Facultad de Filosofía y Letras de la Pontificia Universidad Católica Argentina (UCA). Actualmente se desempeña como Profesora Titular Ordinaria de Estética en la Facultad de Filosofía y Letras y en la Facultad de Teología (UCA). Entre los libros propios se destacan: La literatura en la estética de Hans Urs von Balthasar. Figura, drama y verdad (2002), Lenguajes de Dios para el siglo XXI. Estética, teatro y literatura como imaginarios teológicos (2007), Caminos de espiritu y fuego. Mistica, estética, y poesía (2011), y Presencia y ternura. La metáfora nupcial (2014).

Este artículo fue elaborado en base a la conferencia pronunciada en el $V^{o}$ Seminario de Antropología Trinitaria, sobre el tema "Pueblo de Dios, mística del nosotros y Trinidad", organizado por el Celam, en la ciudad de México, del 4 al 7 de julio de 2017.
} 
El logos simbólico, que se manifiesta siempre en la carne concreta y particular de un lenguaje, es uno de los signos culturales distintivos de los pueblos latinoamericanos. Fruto del encuentro entre la eficacia simbólica de los rituales y la palabra, como señala Pedro Morandé (1984: 144-162), no significa oposición al sentido -por eso se lo denomina logos- sino, al contrario, apertura y dilatación de un horizonte de comprensión que integra lo universal y lo particular, la altura y la profundidad, lo temporal y lo perenne. En el símbolo hay dos o más niveles que buscan la unidad sin anular lo propio de cada polo. Esto exige el dinamismo de un "lenguaje hospitalario" que evidencie la tensión que implica habitar la lengua y la cultura del otro, a la vez que recibirlo en la propia casa. De aquí se sigue el vínculo que estableció Paul Ricoeur entre la traducción y la hospitali$\mathrm{dad}^{1}$, lo cual se halla en estrecha relación con su concepto de "metáfora viva", que entiende como discurso lingüístico en el que el símbolo se manifiesta abriendo sentidos siempre renovados y abiertos a lo diverso de $s^{2}$.

Si pasamos al campo teológico, advertimos similar articulación en la estética teológica de Hans Urs von Balthasar (1986) cuando propone la figura de Cristo como lenguaje que revela y oculta el misterio del amor trinitario ${ }^{3}$, según el dinamismo que Buenaventura llamó expressio-impressio ${ }^{4}$.

1 Ricoeur plantea esta cuestión en el horizonte de la traducción acuñando la expresión "hospitalidad lingüística", que aquí parafraseamos poniendo el acento en el diálogo intercultural a través del lenguaje (Ricoeur, 2005: 28).

2 "Las ligazones operan al mismo nivel de los elementos de la naturaleza -cielo, tierra, aire, agua- $[. .$.$] . En el universo sagrado no hay vivientes aquí o allí, sino la vida como$ sacralidad, total y difusa, que se deja ver en los ritmos cósmicos, [...] Este carácter ligado del simbolismo, su adherencia, constituye toda la diferencia entre el símbolo y la metáfora; ésta es una libre invención del discurso, aquél está ligado a las configuraciones del cosmos" (Ricoeur, 1988: 18-19). "Lo que aquí se dice ilumina nuestra propia noción de metáfora viva. La metáfora no es viva sólo en cuanto vivifica un lenguaje constituido. Sí lo es en cuanto inscribe el impulso de la imaginación en un "pensar más» a nivel del concepto. Esta lucha por el «pensar más», bajo la dirección del «principio vivificante», es el alma de la interpretación" (Ricoeur, 1980: 409).

3 "Jesucristo [...] es la Palabra, la Imagen, la Manifestación y la Exégesis de Dios. [...] Él es aquello que expresa, es decir, Dios, pero no aquel a quien expresa, esto es, el Padre. Paradoja incomparable que constituye la fuente originaria de la estética cristiana y, por consiguiente, de toda estética. ¡Qué capacidad de visión exige y presupone captar este punto originario!" (Balthasar, 1986: 31-32; ver también 111. 141-142 y 393-411).

4 "Esto esclarece la relación entre sujeto y objeto y da lugar a los conceptos fundamentales que caracterizan, respecto a la tradición, toda la estética de Buenaventura, estética de la expressio e impressio. El Serafín Crucificado no es sólo objeto de contemplación en el amor. Es activo y se expresa en cuanto imprime las propias llagas a Francisco" (Balthasar, 1986, 265; ver también 278. 282). 
Por su parte, a propósito de la corporeidad del corazón de Jesús, Karl Rahner (1962) desarrolla los principios de una ontología y teología del símbolo, en la que la relación entre éste y lo simbolizado es intrínseca, lo cual le confiere cualidad ontológica de "símbolo real".

Basten estas menciones como puntos de referencia para nuestra propuesta, ya que no podemos realizar aquí una puesta al día de la relevancia actual de esta cuestión con la seriedad que merece. Lo cierto es que, sea por su expresión metafórica, figural y corpórea, la dimensión simbólica está en la base del lenguaje poético, místico y teológico en el que expresamos la relación del hombre con Dios y a Dios mismo. Es por ello que dicho lenguaje constituye un verdadero logos que acontece en la recíproca hospitalidad lingüística que se da en el "entre" del yo y el tú, es decir, en el espacio relacional del nosotros (Scannone, 2014: 194) ${ }^{6}$.

Sobre la base de estos supuestos, primero, presentaremos la relación entre lenguaje y antropología trinitaria a fin de ubicar nuestro aporte en el marco del texto programático de este seminario. En segundo lugar, para responder al desafío de crear un lenguaje para decir el misterio trinitario, pondremos en diálogo la poesía y ensayos de Octavio Paz con las tesis de ontología trinitarias referidas al lenguaje de Klaus Hemmerle. Por último, en la tercera parte, abriremos el debate sobre la relación entre el logos simbólico, la mística del nosotros y la posibilidad (¿imposible?) (Derrida \& Dufourmantelle, 2000: 31, 81-83) ${ }^{7}$ de una cultura de la hospitalidad.

\footnotetext{
5 "La humanidad de Cristo es verdaderamente la manifestación del Logos mismo, su símbolo real en el sentido más eminente y no sólo lo en sí ajeno a él y su realidad, asumido sólo desde fuera, como un instrumento, para manifestarse, de forma que él no muestre en realidad nada del que lo emplea. [...] Y es que símbolo, en una verdadera teología del símbolo, desde las últimas posiciones fundamentales del cristianismo, no significa algo que, separado de lo simbolizado -o en tanto distinto unido, real o conceptualmente, de forma meramente aditiva con lo simbolizado- lo señale y esté así vacío de ello. Símbolo es, por el contrario, la realidad que como elemento intrínseco de sí misma, constituida por lo simbolizado, lo revela, lo manifiesta y, en tanto existencia concreta de lo simbolizado mismo, está llena de ello" (Rahner, 1962: 304 y 319-320).

6 En el artículo que se dio como marco para el tema de este seminario, J. C. Scannone entiende el "nosotros" no como una totalidad compacta o dialéctica de sujeto y objeto, sino como una interrelación ética entre el yo, el tú y el él/ella. Esta relación, acota, ya se da en el lenguaje y encuentra su fundamento teológico en la doctrina trinitaria de Ricardo de san Víctor del Espíritu Santo como el co-dilectus o co-amado (sic).

Ha sido Derrida quien planteó la imposibilidad de una hospitalidad absoluta e incondicional.
} 


\section{LENGUAJE Y ANTROPOLOGÍA TRINITARIA: SIGNIFICADO Y MÉTODO}

Cuando comencé a esbozar el aporte que podía realizar desde la perspectiva estética a los ejes temáticos propuestos para este encuentro -pueblo de Dios, mística del nosotros y Trinidad- me resultó decisiva la importancia que Piero Coda le otorga al lenguaje en el texto programático de este Seminario de Antropología Trinitaria (Coda, 2014a: 23-50). En efecto, allí desarrolla articuladamente el significado y el método de este seminario, al punto que pensar y decir el acontecimiento trinitario son presentados como parte del mismo desafío. Por ello, en este primer momento plantearé la relación entre lenguaje y significado, por un lado, y entre lenguaje y método, por otro.

2.1. Lenguaje y significado: compromiso lingüístico y acogida del misterio trinitario

Tras señalar el carácter esencial y constitutivo de pensar la Trinidad en relación a nuestra experiencia, a nuestro destino personal y colectivo de seres humanos, el texto plantea la siguiente restricción:

Sin embargo, [agradecidos] por este beneficio sin el cual ya no podemos ni vivir ni pensar como cristianos, no podemos subestimar un límite llamativo o, más bien una apertura al futuro - que podemos reconocer como tal sólo hoy: la transformación sólo inicial, aunque decisiva, del cuadro epistémico, metafísico y conceptual derivado del legado griego, [de] forjar un lenguaje capaz de transmitir esta realidad, con el peligro de disminuir la novedad disruptiva de la llegada de Cristo en Dios, sea en términos de percepción y expresión de la imagen de Dios como en términos de percepción y comprensión de la imagen del hombre. De este hecho, constatamos las consecuencias sobre todo hoy, cuando, por ejemplo, el lenguaje con el cual se expresa la fe haciendo uso de esta conceptualidad a menudo llega a ser incompatible con las categorías en las que hoy dice la conciencia. Fue Klaus Hemmerle, de manera específica y aguda, que llamó la atención sobre este hecho y sobre las consecuencias del esfuerzo, invitando a reanudar con energía y coraje el compromiso lingüístico y conceptual [derivado] de la acogida, en la conciencia humana, del acontecimiento de Dios Trinidad. (Coda, 2014a: 28-29)

Este pasaje ha sido el punto de partida de esta reflexión: mostrar que el lenguaje estético de la poesía es un camino para renovar el lenguaje teológico, a fin de hacer justicia a la realidad trinitaria que se hace experiencia en la acogida del otro. El límite -que el texto pide no subestimar-consiste en no olvidar que en un planteo antropológico hoy no puede estar ausente 
una consideración sobre el lenguaje, lo cual consecuentemente tiene efectos sobre la reflexión trinitaria.

¿Por qué la opción por el lenguaje poético? Porque es un lenguaje disruptivo que por sus características podría potencialmente contribuir a mantener viva la novedad del acontecimiento trinitario en la historia. Esta disrupción proviene desde dentro del acto poético a la vez que es suscitada por la llegada del otro. Por ello, nos resultó una matriz adecuada para la configuración de un lenguaje teológico que busque expresar la experiencia trinitaria realizada por el hombre en sí y desde sí en relación con los otros. A la hora de elegir un poeta, me decidí por la poética de vanguardia del nobel mexicano. ¿Por qué Octavio Paz? Porque tanto su poesía como los ensayos en los que reflexiona sobre el acto poético ofrecen un corpus a partir del cual pensar sobre la peculiaridad del logos simbólico como lenguaje hospitalario que es el objetivo final que nos hemos propuesto.

\subsection{Lenguaje y método: transdisciplinariedad y logos ampliado}

Consideremos ahora el segundo núcleo del texto programático, el método, y su relación con el lenguaje. En virtud del principio trinitario de la circularidad entre teología y antropología, en base a la cual se propone configurar el método de una antropología trinitaria, Coda destaca "una necesaria recuperación saludable, rigurosa y equilibrada de la interdisciplinariedad, aún mejor, y más en profundidad, de la transdisciplinariedad del conocimiento" (Coda, 2014a: 41). A fin de evitar las trampas de la confusión y de la separación, se invita a incorporar la dimensión "trans" de la reciprocidad trinitaria adoptando una "epistemología existencial", "con conciencia crítica" y "evangélica ingenuidad virginal" (Coda, 2014a: 47), de modo tal que las voces de las ciencias humanas y sociales se unan al coro de la filosofía y la teología para conformar una misma "carne" de relaciones.

La transdisciplinariedad se me presentó, pues, como el ámbito epistemológico adecuado para realizar el diálogo entre lenguaje poético y antropología trinitaria. De acuerdo con esto y siguiendo las orientaciones del mismo texto programático, mi propuesta consiste en trazar "con energía y coraje" la huella del compromiso con un logos ampliado que asuma la dimensión simbólica, metafórica y figural constitutivas de la palabra poética, a fin de integrar la dimensión existencial de la irrupción dramática de la novedad histórica de Dios en Cristo en la cultura mestizada de los pueblos latinoamericanos. 
3. CREAR Un NUEVO LENGUAJE: CORRESPONDENCIAS ENTRE POESÍA Y ONTOLOGÍA TRINITARIA

En el siglo del giro lingüístico no debería sorprendernos el común interés por el lenguaje entre hombres nacidos en geografías y contextos diferentes pero que compartieron el mismo tiempo histórico. Poeta y ensayista mexicano, Octavio Paz es, como creador y pensador reconocidamente agnóstico, uno de los más destacados representantes de la literatura latinoamericana del siglo XX. Teólogo y fenomenólogo alemán, Klaus Hemmerle se sumó a la búsqueda de una ontología postcrítica renovada, situando analógicamente en la misma línea el darse recíproco y comunional con el pensar, el hablar y el ser (Hemmerle, 2005: 59-61).

A pesar de la distancia de disciplinas y motivaciones, ambos coincidieron en el mismo diagnóstico de caducidad de sus lenguajes: poético, el uno, filosófico y teológico, el otro. Ambos advirtieron sobre la urgencia de poner en acto la gestación de un lenguaje nuevo y, por ello, cada uno en lo suyo puede ser considerado genuinamente como un creador.

\subsection{La poesía como "la otra voz": circularidad y novedad}

Octavio Paz (1994) definió la palabra poética como "la otra voz", que desoculta "el otro lado de la realidad" que todo hombre lleva dentro de sí, pero que se pone en acto, precisamente, cuando se trasciende a sí mismo estableciendo una relación con los otros en el devenir de la historia ${ }^{8}$. La poesía pertenece para él al ámbito del rito que reproduce "la experiencia mística" de la "otra orilla", representada en el dinamismo universal de muerte y nacimiento que alienta en el fondo de lo humano. Esta "otra orilla", que está dentro de nosotros mismos, no se realiza sino en la salida de sí hacia el otro. De ahí que, afirma:

Sin movernos, quietos, nos sentimos arrastrados, movidos por un gran viento que nos echa fuera de nosotros. Nos echa fuera y, al mismo tiempo, nos empuja hacia dentro de nosotros. La metáfora del soplo se presenta una y otra vez en los grandes textos religiosos de todas las culturas: el hombre es desarraigado como un árbol y arrojado hacia allá, a la otra orilla, al encuentro de sí. (Paz, 1993: 122)

\footnotetext{
8 "Ahora bien, aunque atada a un suelo y a una historia, [la poesía] siempre se ha abierto, en cada una de sus manifestaciones, aún más allá transhistórico. No aludo a un más allá religioso: hablo de la percepción del otro lado de la realidad. Es una experiencia común a todos los hombres en todas las épocas y que me parece anterior a todas las religiones y filosofías" (Paz, 1994: 226).
} 
En dos versos sintetiza este dinamismo de alteridad habitada a la vez que abierta al otro, cuando recordando la figura de quien lo inició en la literatura, dice: "me enseñó a ver con los ojos cerrados, / ver hacia adentro y a través del muro" (citado por Ruy Sánchez, 2013: 25). Los ojos cerrados, porque, para crear, el poeta después de ver ha de imaginar. En el adentro está la morada de la memoria que es la fuente de las imágenes creadoras. Sin embargo, O. Paz se propuso ir más allá del muro que lo separaba del mundo y optó por mirar al otro atravesándolo, para lo cual hubo de derribar muchos obstáculos, tantos como los que quizás tengamos que atravesar nosotros si queremos renovar el lenguaje a partir de la experiencia de comunión.

La renovación poética que emprendió $\mathrm{O}$. Paz tuvo su punto de partida en la superación de la polarización planteada a principios del siglo XX entre poesía pura y poesía social. Ni la una ni la otra. Resistió la irreductibilidad de las posturas y se abrió paso hacia un camino distinto. Claramente fue su opción por la alteridad — "la otra orilla", "la otra voz" — la que originó la novedad de un lenguaje en el que logró integrar forma e historia. La conciencia de la presencia del misterio como inaccesibilidad absoluta, señala, "no es sino la expresión de la otredad, de eso Otro que se presenta como algo por definición ajeno o extraño a nosotros" (Paz, 1993: 147-148). Así, el origen de la palabra poética es la experiencia del "desde donde" ontológico de la relación con el otro que vive en el mundo y en la historia (Ruy Sánchez, 2013: 16). Así describe el proceso creador que da a luz al poema:

Como la religión, la poesía parte de la situación humana original -el estar ahí, el sabernos arrojados en ese ahí que es el mundo hostil o indiferente- y del hecho que la hace precaria entre todos: su temporalidad, su finitud. Por una vía que, a su manera, es también negativa, el poeta llega al borde del lenguaje. Y ese borde se llama silencio, página en blanco. Un silencio que es como un lago, una superficie lisa y compacta. Dentro, sumergidas, aguardan las palabras. Y hay que descender, ir al fondo, callar, esperar. La esterilidad precede a la inspiración, como el vacío a la plenitud. La palabra poética brota tras eras de sequía. Mas cualquiera que sea su contenido expreso, su concreta significación, la palabra poética afirma la vida de esta vida. Quiero decir. El acto poético, el poetizar, el decir del poeta -independientemente del contenido particular de este decir- es un acto que no constituye, originalmente al menos, una interpretación, sino una revelación de nuestra condición. Hable de esto o de aquello, de Aquiles o de la rosa, del morir o del nacer, del rayo o de la ola, del pecado o de la inocencia, la palabra poética es ritmo, temporalidad manándose y regenerándose sin cesar. (Paz, 1993: 129) 
El paralelismo con la gestación de una palabra teológica que quiera mantenerse al ras de la experiencia puede ser muy iluminador. Como un ejemplo entre tantos, podemos tomar el símbolo del árbol que el poeta convierte en metáfora de esa otra voz. ontológica, que se actualiza cuando el yo lírico es mirado por un tú concreto. Así, en el poema "Árbol adentro":

Creció en mi frente un árbol.

Creció hacia dentro.

Sus raíces son venas, nervios sus ramas,

Sus confusos follajes pensamientos.

Tus miradas lo encienden

y sus frutos de sombras

son naranjas de sangre,

son granadas de lumbre.

Amanece

en la noche del cuerpo.

Allá adentro, en mi frente,

El árbol habla.

Acércate, ¿lo oyes?”. (Paz, 1987: 137)

“Tus miradas lo encienden": este es el verso clave. Con la metáfora del árbol narra la génesis de la poesía, que es palabra viva porque es corpórea, como lo indican las imágenes de las venas, nervios, sangre, pero que es también pensamiento, razón y sensibilidad integrados en el mismo logos por la acción de la imaginación creadora. En un primer movimiento, la mirada del tú vivifica al árbol, metáfora del yo, a cuyos pensamientos le da nueva voz. Casi simultáneamente, en un segundo movimiento, el yo le devuelve al tú la palabra renovada, amanecida, gestada en el dolor de la noche "del cuerpo". Hay una kénosis, un vaciamiento de sí, en el darse al otro en la palabra. El poema se cierra con una pregunta que interpretamos como una invitación a entrar en la circularidad hospitalaria del lenguaje. Bien podemos establecer aquí una relación analógica con la plurioriginariedad de la palabra que K. Hemmerle plantea como una consecuencia de la primacía del verbo por sobre el sustantivo:

Mi palabra tiene, por lo menos tres orígenes: yo, el lenguaje, tú. [...] Los tres orígenes brotan reciprocamente - de diferente manera en mi palabraen cada origen se halla enteramente el mismo proceso, pero de manera distinta. Las participaciones de los orígenes no se pueden cuantificar, pero sí diferenciar, por el hecho de cómo brota de cada origen la totalidad. (Hemmerle, 2005: 54) 
Así también en el poema que acabamos de analizar se da la circularidad entre el yo, el tú y el lenguaje. De esta circularidad recíproca, que es la primera nota derivada de la "otra voz", brota a su vez la novedad de la palabra, segunda de las notas distintivas de la búsqueda poética de Paz. El campo semántico de lo nuevo se relaciona con lo que permanece todavía oculto. Sólo algunos versos más que den cuenta de esta afirmación:

Las puertas del año se abren, como las del lenguaje, hacia lo desconocido.

Anoche me dijiste: mañana

habrá que trazar unos signos, dibujar un paisaje, tejer una trama sobre la doble página

del papel y del día.

Mañana habrá que inventar, de nuevo, la realidad de este mundo. (Paz, 1987: 138)

La condición de lo nuevo se encuentra en relación con el desvelar más que con el inventar. El lenguaje poético es dinámico, abierto al futuro, a lo que no existe aún. Es el dominio de la imaginación que traza, dibuja y teje sobre el papel y en la vida. Este desafío es el que está llamado a asumir el lenguaje teológico si quiere proferir una palabra que brote desde el interior de la experiencia trinitaria del misterio de Dios.

La circularidad y la novedad, que acabamos de describir, no son para el ensayista mexicano notas exclusivas de una cultura determinada, sino que, por su referencia al origen, el logos poético así concebido se halla en la base de toda cultura, sea como narración, sea como canto. Así propone el ensayista mexicano la función universal a la par que regional de esa "otra vOZ":

En otras culturas, la poesía no sólo estaba íntimamente asociada a la religión y la mitología sino a las otras artes. Sabemos, por ejemplo, que los aztecas recitaban, cantaban y, lo que es más notable, bailaban sus poemas. Otro rasgo común a las antiguas sociedades: las cofradías, hermandades y órdenes de poetas. Estas agrupaciones con frecuencia desempeñaban funciones religiosas y litúrgicas. En muchos pueblos los poetas eran considerados videntes y adivinos. Fue una creencia generalizada que se explica, muy probablemente, por lo siguiente: el poeta conocía el futuro porque conocía el pasado. Su saber era un saber de los orígenes. En todas aquellas sociedades el presente y el futuro eran, en 
el sentido matemático de la expresión, funciones del pasado. (Paz, 1994:

213)

En estas dos notas queda sintetizada la propuesta de su logos poético simbólico: por un lado, circularidad entre el poeta, el receptor y el lenguaje; por otro, novedad como dinamismo que desde la fuente se proyecta hacia el sentido de lo que está en la "otra orilla", en eso universal que está más allá del tiempo presente, en el futuro y que configura cada cultura en su particularidad.

3.2. La estructura lúdica del lenguaje en la ontología trinitaria de K. Hemmerle

La relevancia que $\mathrm{K}$. Hemmerle le confiere al verbo orienta la nueva ontología hacia el acontecer de la vida, a una actualización permanente del "desde dónde" y del "hacia dónde" (Hemmerle, 2005: 50-52). Como ya dijimos en este dinamismo sitúa el fenomenólogo la palabra, toda palabra, también y sobre todo la poética, aunque no lo desarrolle específicamente en sus tesis de ontología trinitaria. La centralidad del verbo lo conduce a proponer una estructura lúdica donde la plurioriginariedad de la palabra pueda acontecer. Esto amplía el horizonte del lenguaje ad infinitum por medio de la operación del comparativo, porque cada uno de los miembros en juego se entrega y se dice recíprocamente desde sí hacia el otro, en un "siempre más" dinámico y creciente. Afirma al respecto:

La vida es idéntica consigo al progresar, al crecer; la vida sigue siendo vida cuando lleva a ser más vida. El lenguaje sigue siendo lenguaje cuando sigue hablando, cuando dice más cosas, cuando interpela más al otro. El tiempo sigue siendo tiempo cuando impulsa más hacia el futuro, hacia un futuro mayor. (Hemmerle, 2005: 55-56)

Justamente este plus es la característica propia del lenguaje poético. No se trata simplemente de decir, sino de decir más. No se trata sólo de interpelar al otro para entrar juntos en el juego serio de la reciprocidad del darse en el decirse, sino de interpelar más. Y esto sucede porque el lenguaje poético es dinámico y abierto a lo desconocido, a lo nuevo. Como el lenguaje figural, se halla abierto al origen, al otro, al ser. Este más es la apertura a la acción, que es juego y es drama.

Pues bien, al tratar la analogía del lenguaje en relación con la analogía del ser, K. Hemmerle establece una relación ontológica entre el pensar y la palabra que nosotros vemos realizada en el lenguaje poético simbólico (Hemmerle, 2005: 59-61). Asimismo, también propone analógicamente la 
relación entre pensamiento y lenguaje como un juego. Dicho con sus propias palabras:

Leído desde abajo, desde la inmediatez del juego, eso podrá ser una cosa última, una cosa suprema, lo más análogo de todas las analogías, aquella en la que nosotros experimentamos de manera suma el ser y el pensar como un límite que en el juego nos remite más allá del juego: el misterio, Dios mismo aparece como remitido al juego de la analogía. (Hemmerle, 2005: 63)

La estructura lúdica aquí planteada abre otra senda en el proceso del nuevo lenguaje para decir a Dios que estamos buscando en el logos poético simbólico. Otra vez nos encontramos ante la potencia decidora del comparativo: el misterio es el "más allá" del juego analógico. Desde aquí el lenguaje se abre al nosotros, porque, dice, "el juego lo jugamos, cada uno a partir de sí; lo jugamos, pero jugando cada uno en relación mutua, como asignados al papel del nosotros" (Hemmerle, 2005, 62). Dicho lo cual, estamos en condiciones de avanzar hacia la tercera parte de nuestro planteo, donde trataremos la relación entre el lenguaje simbólico y hospitalidad incorporando la dimensión comparativa y analógica del juego.

\section{MístiCA DEL NOSOTROS Y CULTURA DE LA HOSPITALIDAD}

El aporte de O. Paz al diálogo entre logos simbólico y antropología trinitaria quedó representado en la metáfora de "la otra voz" y sus dos notas derivadas de circularidad recíproca y novedad. El aporte de la ontología trinitaria de K. Hemmerle fue considerado desde la situación analógica y lúdica del lenguaje. Expresamente dejamos para esta tercera parte la referencia a la dimensión simbólica del lenguaje del cuerpo, para tratarlo en el horizonte del amor, que es a la vez eje de la mística del nosotros y de la hospitalidad.

4.1. De la soledad existencial a la poesía de comunión: el amor hecho cuerpo

En el cuarto centenario del nacimiento de Juan de la Cruz, el mexicano pronuncia una conferencia titulada "Poesía de soledad y poesía de comunión”. Allí distingue entre mística y poesía. La mística como la actitud ante lo sagrado en sentido amplio es "el entregarse a lo absoluto y confundirse con Dios", "diálogo y relación amorosa con el Creador". La poesía, en cambio, es diálogo con el mundo, en el que: 
[...] hay dos situaciones extremas: una de soledad; otra, de comunión. El poeta siempre intenta comulgar, unirse (reunirse, mejor dicho), con su objeto: la propia alma, la amada, Dios, la naturaleza... La poesía mueve al poeta hacia lo desconocido. [...] La mística es una inmersión en lo absoluto; la poesía es una expresión de lo absoluto o de la desgarrada tentativa para llegar a él. [...] Porque la poesía, que es un testimonio del éxtasis, del amor dichoso, también lo es de la desesperación. En la comunión, el poeta descubre la fuerza secreta del mundo. [...] Los poetas han sido los primeros que han revelado que la eternidad y lo absoluto no están más allá de nuestros sentidos sino en ellos mismos. (Paz, 1974: 97. 99-101)

Este es el contexto en el que Juan de la Cruz es presentado como el hombre nuevo en quien se reconcilian los contrarios, pues ha realizado "la más intensa y plena de las experiencias: la de la comunión." Y añade lacónicamente: "Un poco más tarde esa comunión será imposible" (Paz, 1974: 102-103).

Dos temas a subrayar aquí: por un lado, la relación entre el lenguaje poético y el cuerpo; por otro, la identificación del poeta y místico Juan de la Cruz con la comunión. Ambos lenguajes hallan en la experiencia de los amantes la metáfora que expresa la unión: con el mundo y con Dios (Meléndez Guerrero, 2016: 439-450). Cuerpo y comunión se le presentan como inseparables. San Juan de la Cruz ya había planteado claramente la relación entre experiencia mística y lenguaje en el Prólogo del Cántico Espiritual donde señalaba que las "figuras, comparaciones y semejanzas" eran el medio más apropiado para "manifestar con palabras", lo que Dios daba a entender "a las almas amorosas, donde él mora" (2007: 566-568). Sin embargo, si bien este morar es trinitario, el contexto histórico no estaba preparado aún para realizar el giro hacia una "mística del nosotros", la cual consiste en "transferirse" a amar no sólo a Dios en sí, sino a Dios en el corazón del hermano (Coda, 2014a: 134-140). Esto repercute directamente sobre el lenguaje ya que "estoy llamado a amar no sólo el silencio sino también la palabra, es decir, la comunicación de Dios en mí con Dios en el otro" (Coda, 2014a: 140).

Al ingresar en el dinamismo lúdico e interpersonal, el logos simbólico se vuelve hospitalario. El cuerpo deja ya de ser instrumento en el que el alma se manifiesta, para ser el lugar mismo de la manifestación del sentido. Esta realidad que Octavio Paz no llega a expresar en su prosa, sí la barrunta en su poesía. En el final de "Piedra de sol", tras narrar metafóricamente la historia de su pueblo mexicano, se adentra en la experiencia mística ancestral de la relación del hombre con los mitos de la tierra. Es justamente aquí 
donde adopta explícitamente el lenguaje interpersonal y corpóreo de ser el yo desde el tú en el nosotros, diciendo:

[...] ¿la vida, cuándo fue de veras nuestra?, ¿cuándo somos de veras lo que somos?, bien mirado no somos, nunca somos a solas sino vértigo y vacío, muecas en el espejo, horror y vómito, nunca la vida es nuestra, es la de otros, la vida no es de nadie, todos somos la vida -pan de sol para los otros, los otros todos que nosotros somos-, soy otro cuando soy, los actos míos son más míos si son también de todos, para que pueda ser he de ser otro, salir de mí buscarme entre los otros, los otros que no son si yo no existo, los otros que me dan plena existencia, no soy, no hay yo, siempre somos nosotros, la vida es otra, siempre allá, más lejos, fuera de ti, de mí, siempre horizonte, vida que nos desvive y enajena, que nos inventa un rostro y lo desgasta, hambre de ser, oh muerte, pan de todos, $[\ldots]$

Eloísa, Perséfone, María, muestra tu rostro al fin para que vea mi cara verdadera, la del otro, mi cara de nosotros siempre todos, cara de árbol y de panadero, de chofer y de nube y de marino, cara de sol y arroyo y Pedro y Pablo, cara de solitario colectivo, despiértame, ya nazco: vida y muerte

pactan en ti, señora de la noche, $[\ldots]$ abre la mano, señora de semillas que son días, el día es inmortal, asciende, crece, acaba de nacer y nunca acaba, cada día es nacer, un nacimiento es cada amanecer y yo amanezco, amanecemos todos, amanece el sol cara de sol, Juan amanece 
con su cara de Juan cara de todos, puerta del ser, despiértame, amanece, déjame ver el rostro de este día, déjame ver el rostro de esta noche, todo se comunica y transfigura, arco de sangre, puente de latidos, llévame al otro lado de la noche, adonde yo soy tú somos nosotros, al reino de pronombres enlazados (Paz, 2014: 238-239).

La hospitalidad poética aparece aquí expresada en el entramado pronominal de la primera y segunda persona singular con la tercera plural unidas por la acción del "somos" y en el significado pasivo de los verbos escogidos, que se encuentran reforzados por las preposiciones que indican movimientos en el espacio: acoger, cuidar y recibirse los unos a los otros, en los otros, con los otros. Cada uno de los particulares se hallan reunidos en el mismo "somos" del nosotros. La persona es constitutivamente relacional y, por tanto, el yo es en apertura y entrega al tú: el yo es desde el tú y, por tanto, "soy" se realiza en el "somos".

La poesía tiene su origen en esta experiencia que describe como paso de la soledad a la comunión, del silencio a la palabra. En este morar de "pronombres enlazados" está la intuición de un "nosotros" que no es disolución persona sino afirmación de su constitutiva relacionalidad. En este "nosotros" habitado de rostros, también se le hace lugar al cosmos. Esta es la herencia de la cosmovisión de las culturas originarias en la que la naturaleza divinizada fluye en la palabra poetizada sin barreras que las separen.

4.2. Hacia la configuración de una cultura de la hospitalidad: ecos y resonancias del debate

Del análisis realizado se desprende que el "nosotros" inclusivo y abierto a todos es el lugar teológico de la hospitalidad. El aporte del logos simbólico en el lenguaje poético de la metáfora, de la figura y del cuerpo resulta decisivo en vistas a la renovación de un logos que exprese existencialmente el misterio trinitario. La interculturalidad de los pueblos latinoamericanos es el espacio donde se despliega una hospitalidad posible. Para llevar a cabo el compromiso lingüístico y conceptual que se deriva de la acogida del acontecimiento trinitario se requiere energía y coraje, pues implica un vaciarse de sí para hacerse el otro en el tercero.

Por todo lo cual, el lenguaje es un aporte importante y necesario a la intencionalidad de nuestra búsqueda de una Antropología trinitaria que 
hasta ahora no había aparecido en el itinerario recorrido. Y esto es así porque la Antropología trinitaria es tal en cuanto se hace lenguaje, pues éste es el lugar donde se vuelve evidente que la persona humana se hace tal en Dios, en la búsqueda del otro, en la hospitalidad del otro.

El tema presenta diferentes niveles de estratificación. Por ello resulta muy acertadamente planteado el lugar epistémico: la transdisciplinariedad. Cada uno de estos niveles nos interpela a continuar la reflexión y a profundizar en las perspectivas abiertas. El lenguaje es considerado en tres niveles: estructura formal, acontecimiento y vocación ontológica.

Como estructura formal, el primer nivel del lenguaje es el del logos simbólico. Redescubierto por el pensamiento contemporáneo, el lenguaje es palabra encarnada, logos simbólico. Como lo advirtieron los Padres de la Iglesia, en cuanto tal, la carne se expresa en un lenguaje constituido no sólo por las palabras dichas sino también por los gestos.

El segundo nivel se refiere al lenguaje como acontecimiento, es decir, como comunicación no de algo ya dado sino como acontecimiento del ser en su relación compartida con el otro, como bien lo señala Hemmerle. En consecuencia, el lenguaje no es sólo la comunicación de un yo a un tú y de un tú a un yo, sino es la conjunta creación del tercero, la posibilidad de comunicarse en el tercero. De aquí se sigue la cualidad del lenguaje como acontecimiento trinitario. No sólo relación yo-tú sino epifanía abierta del nosotros en cuanto tal: el siempre más del advenimiento de Dios entre nosotros.

El tercer nivel lo constituye la vocación ontológica del lenguaje como hospitalidad, es decir, como traducción, como diálogo intercultural. La hospitalidad es de gran importancia en este momento histórico, ya que el desafío de las migraciones, que el papa Francisco lee como el signo de los tiempos más importante, exige un lenguaje hospitalario, una traducción, un diálogo intercultural.

Hay un texto de Edmond Jabès (2014: 57-59) sobre el fenómeno de la traducción: allí muestra muy bien como la traducción es un acontecimiento trinitario (aunque no usa la palabra) porque en la traducción yo soy llamado a hospedar en mí el concepto y el símbolo generado por otra cultura y a expresarlo en mi carne cultural y esto es una creación porque en mi cultura no está precisamente lo que está dicho en otra cultura. En la relación dialógica se puede expresar la cultura de otro transfigurándose en el otro.

Es muy sugerente el entrecruzamiento de niveles y la elección de la obra de Octavio Paz. En algunos pasajes es sorprendente la confirmación del camino de la ontología trinitaria que estamos transitando. A través de la hermenéutica teológica trinitaria, la obra del poeta mexicano aparece 
como un esbozo vivido de ontología de la palabra poética en tanto el lenguaje se convierte en expresión de la otredad: sea como irrupción y encarnación en la palabra otredad, sea como comunicación creativa de ella al otro en el diálogo de la "reciprocidad reciprocante" (Coda, 2014b: 657; 2018: 22-23), puesto que la reciprocidad es verdadera reciprocidad cuando es reciprocante, es decir, cuando está abierta al otro, al tercero.

Pero el aspecto más sugerente de esta perspectiva es la relación entre el lenguaje poético simbólico y la hospitalidad, lo cual se subraya en la referencia de Octavio Paz a Juan de la Cruz en cuanto a la mística y la poética de la comunión. En efecto, en la lectura de Juan de la Cruz que realiza Octavio Paz, el acento está puesto en la irrupción del Absoluto en la palabra del poeta que transmite y comunica esta palabra a los otros, la que sin embargo no es todavía la comunicación de la experiencia del nosotros. Poéticamente, Octavio Paz va más allá que Juan de la Cruz. Cuando dice "adonde yo soy tú somos nosotros" realiza una hermenéutica de lo que dice Juan de la Cruz respecto de la unión mística. Octavio Paz introduce aquí el nosotros que en Juan de la Cruz no está explícito. Es la sensibilidad contemporánea la que hace emerger esta dimensión al descubrir la presencia del nosotros en la cosmovisión de las culturas originarias. De este modo, en el lenguaje poético se vuelve evidente una dimensión que en el lenguaje místico de Juan de la Cruz no se hallaba y que Octavio Paz propone a partir de la irrupción del otro. Es la apertura al absoluto la que funda este nuevo camino del nosotros. La poesía de Octavio Paz patentiza así la libertad de la ontología trinitaria.

Se comprueba aquí la intuición de Lucio Gera cuando afirma que la literatura es uno de los mejores caminos teológicos para ingresar en la escucha del pueblo (Avenatti de Palumbo \& Bayá Casal, 2013: 21-22). Existe asimismo un vínculo entre la dinámica expressio-impressio, que Hans Urs von Balthasar toma de san Buenaventura e incorpora al núcleo de su estética teológica, y el lenguaje poético simbólico. La relación entre estética y hospitalidad es ciertamente una pista para mejor comprender al Dios del pueblo y su expresión "teopoética" como nota distintiva de la teología latina propuesta por Roberto Goizueta (2010).

El "logos poético simbólico" crea un mundo nuevo. En esta nueva creación es muy importante el silencio. Este logos poético simbólico puede interpretarse como un poder silencioso y dinámico, en el que acontece la teofanía. Aquí se puede ver la semejanza entre el logos poético del nosotros y la poesía del pueblo. Desde este punto de vista, la posición de la teología latina desarrollada por R. Goizueta no coincide con la teoría poética de Paz, en la medida en que subraya la relación entre lenguaje poético y lenguaje político, en el que se vinculan el lenguaje simbólico con el lenguaje de la religiosidad popular en América Latina. 
Es necesario tener en cuenta que el logos simbólico es más abarcador que el logos poético dado que éste es expresión del primero. El poder silencioso de lo posible constituye un momento del proceso creador del poeta. Ya en su temprana obra El arco y la lira, Paz planteó su búsqueda de una voz poética que no es ni pura forma ni puro compromiso político, sino algo diverso. Es notable su esfuerzo por distinguir su posición centrada en el acto creador. Justamente en este punto se halla la correspondencia con la idea del verbo en Hemmerle. No se trata de la poesía como resultado sino del acto poético, que Paz concibe en relación con la historia, con el mundo y con el cosmos. Cuando plantea la poesía como la "otra voz", no está pensando en una voz de trascendencia: no tiene una preocupación teológica, ya que no sólo se declara agnóstico, sino que es crítico de la religión como tal (sobre todo de la religión católica), lo cual explica su orientación hacia el budismo. En ese sentido, Paz no se reconocería en una "teopoética" de orientación política como la que presenta hoy la teología latina. Paz buscó transitar un nuevo camino desideologizado: el de la relación ontológica entre ser y lenguaje, análoga a la que establece Coda en el texto programático de este Seminario de Antropología trinitaria. En ambos casos el lenguaje surge desde adentro. Es importante señalar una vez más que la hospitalidad aparece en Paz precisamente cuando introduce la dimensión corpórea y amatoria, estableciendo un estrecho vínculo entre cuerpo, eros y lenguaje. Hoy el compromiso político es otro: no pasa por las ideologías sino por las personas concretas, por la relacionalidad del encuentro interpersonal.

El proceso de la analogía del símbolo, tal como lo desarrolla Jean Ladrière $(1970 ; 1984 ; 2004)$ en relación con la poesía mística de Juan de la Cruz, es el nuevo lenguaje que todavía no existe. Dicha experiencia que aún no tiene lenguaje lleva al poeta a buscar el lenguaje en otro ámbito de la realidad. De este modo, a través de un proceso de simbolización, el poeta es capaz de encontrar una manera de nombrar lo nuevo que ha experimentado. Por eso resulta muy interesante situar el punto de encuentro en el acto creador.

Esta focalización en el acto creador permite pensar en la acción del Espíritu como el tercero que despierta y conduce este proceso de simbolización hacia una pragmática. El Logos no se dice a sí mismo sino al otro, al Padre: el Logos dice el silencio del Padre en el Amor, es decir, en la comunión. La verdad del Logos es decir al otro, el Padre, como Amor, el Espíritu. De esta manera, el logos poético simbólico encuentra en la antropología trinitaria la posibilidad de abrirse a la dimensión pneumatológica en la que el Padre se dice en el Verbo del Amor y en el Amor del Verbo. Se inaugura así una teoría trinitaria del lenguaje que encuentra en la hospitalidad su nuevo nombre. 


\section{REFERENCIAS}

Avenatti de Palumbo, C., \& Bayá Casal, P. (2013). Estética y literatura: Experiencia y lenguaje. Entrevista a Lucio Gera (1924-2012). Teología, (110), 11-22.

Balthasar, H. U. von. (1986). Gloria. Una Estética teológica. 1. La percepción de la forma. Madrid: Encuentro.

Coda, P. (2014a). Trinidad y Antropología. En AA.VV. Antropología trinitaria para nuestros pueblos (pp. 23-50, 125-151). Bogotá: Centro de Publicaciones del CELAM.

Coda, P. (2014b). Desde la Trinidad. El advenimiento de Dios entre historia y profecía. Salamanca: Secretariado Trinitario.

Coda, P. (2018). Para una ontología trinitaria. Si la forma es relación. Buenos Aires: Agape Libros.

Derrida, J., \& Dufourmantelle, A. (2000). La hospitalidad. Buenos Aires: Ediciones de la Flor.

Goizueta, R. (2010). Christ our Companion, Toward a Theological Aesthetics of Liberation. New York: Orbis Book.

Hemmerle, K. (2005). Tras las huellas de Dios. Ontología trinitaria y unidad relacional. Salamanca: Sígueme.

Jabès, E. (2014). El libro de la hospitalidad. Madrid: Trotta.

Juan de la Cruz, san (2007). Cántico Espiritual (CB). En Obras completas. Salamanca: Sígueme.

Ladrière, J. (1970). L'articulation du sens. 1. Discours scientifique et parole de la foi. Cerf: Paris.

Ladrière, J. (1984). L'articulation du sens. 2. Les langages de la foi. Cerf: Paris.

Ladrière, J. (2004). L'articulation du sens. 3. Sens et vérité en théologie. Cerf: Paris.

Meléndez Guerrero, L.G. (2016). "Todo amor es eucaristía”. Octavio Paz y la experiencia del amor como comunión. En C. Avenatti de Palumbo y A. Bertolini (eds.), El amado en el amante. Figuras, textos y estilos del amor hecho bistoria (pp. 439-450). Buenos Aires: Agape Libros.

Morandé, P. (1984). Cultura y modernización en América Latina. Santiago de Chile: Instituto de Sociología de la Pontificia Universidad Católica de Chile.

Paz, O. (1974). Poesía de soledad y poesía de comunión. En Las peras del olmo, Barcelona: Seix Barral.

Paz, O. (1987). Árbol adentro. Buenos Aires: Seix Barral.

Paz, O. (1993). El arco y la lira. El poema, la revelación poética. Poesía e historia. México: Fondo de Cultura Económica.

Paz, O. (1994). La otra voz: poesía y fin de siglo. En Obras Completas de Octavio Paz. La casa de la presencia. México: Fondo de Cultura Económica, Club de Lectores.

Paz, O. (2014). Piedra de sol. En Obra poética (1935-1998). Barcelona: Galaxia Gutenberg/ Círculo de Lectores.

Rahner, K. (1962). Para una teología del símbolo. En Escritos de Teología 4 (pp. 283-319). Madrid: Taurus.

Ricoeur, P. (1980). La metáfora viva. Madrid: Europa. 
Ricoeur, P. (1988). Palabra y símbolo. En Hermenéutica y acción (pp. 7-25). Buenos Aires: Docencia.

Ricoeur, P. (2005). Sobre la traducción. Buenos Aires: Paidós.

Ruy Sánchez, A. (2013). Una introducción a Octavio Paz. México: Fondo de Cultura Económica.

Scannone, J. C. (2014). El sujeto comunitario de la espiritualidad y mística populares. Stromata, 70(2), 183-196. 